\title{
Pengembangan Aplikasi E-Raport Berbasis Graphical User Interface (GUI) dengan Menggunakan VB.Net 2010 di SMKN 10 Bima
}

\author{
Mustakim $^{1}$, Nur Fitrianingsih ${ }^{2, *}$, Ita Fitriati ${ }^{3}$ \\ 1,2,3 STKIP Taman Siswa Bima \\ ․ㅡurfitrianingsih984@gmail.com \\ ${ }^{*}$ Coresponding Author (ukuran 9 pt)
}

\section{Artikel Info}

Tanggal Publikasi

2019-06-30

\section{Kata Kunci}

Pengembangan Aplikasi E-Raport

VB. Net 2010

\begin{abstract}
Abstrak
Penelitian ini merupakan penelitian pengembangan (researc and development), yang mengembangkan aplikasi sistem penilaian atau yang disebut e-raport yang dirancang dengan sistem offline sehingga sangat mudah diakses oleh user, subjek penelitian ini adalah siswa kelas X TKJ SMKN 10 BIMA. Model pengembangan yang digunakan dalam penelitian ini adalah model dari Dick \& Carey, Tujuan dari penelitian ini adalah untuk menghasilkan raport yang terotomatisasi dari yang konvensional ke cara yang elektronik, menghasilkan e-raport yang dapat menghindari kesalahan penulisan secara manual, mempermudah guru dalam menginput maupun memperbarui nilai rapor, Penelitian yang dilakukan menghasilkan produk aplikasi sistem e-raport millennium dengan menggunakan Visual Basic Net.2010 dengan model dan tampilan yang cukup menarik dengan berbagai kemudahan dalam pengaplikasiannya. Sistem yang dirancang mampu menghasilkan raport yang sudah terotomatisasi hingan menjadi rapor yang efektif, efisien, dan praktis dalam penggunaannya. Kualitas produk termasuk kriteria "Layak" dengan rata-rata presentasi 80\% - 95\%. Dan sudah memenuhi standar ktiteria yang ditetapkan yakni sebesar 70\%, itu dapat dilihat dari hasil angket yang dilakukan kepada ahli materi dengan hasil angket berupa "layak", ahli media dengan hasil angket berupa "layak", uji dengan kelompok kecil dengan hasil angket berupa "layak", dan uji dengan kelompok besar dengan hasil angket berupa "layak".
\end{abstract}

\section{PENDAHULUAN}

Rapor adalah salah satu hal yang tidak dapat dilepaskan dari instansi yang bergerak di bidang pendidikan. Untuk proses pembuatan atau pengerjaan rapor bermacam-macam, mulai dari proses yang manual sampai dengan proses yang menggunakan perangkat lunak (komputerisasi), di Indonesia sendiri penggunaan sistem penilaian yang secara otomatis sudah banyak diterapkan terutama Sekolah Menengah Kejuruan (SMK). Sekolah Menengah Kejuruan, yang selanjutnya disingkat SMK, adalah salah satu bentuk satuan pendidikan formal yang menyelenggarakan pendidikan kejuruan pada jenjang pendidikan menengah sebagai lanjutan dari SMP, MTs, atau bentuk lain yang sederajat atau lanjutan dari hasil belajar yang diakui sama atau setara SMP atau MTS. Sekolah Menengah Kejuruan (SMK) sebagai bagian dari pendidikan kejuruan, mempunyai tujuan: (1) menyiapkan peserta didik agar menjadi manusia produktif, mampu bekerja mandiri, mengisi lowongan pekerjaan yang ada di pelayanan dunia usaha dan lainnya sebagai tenaga Sutikno, Studi Produktivitas Guru pada Sekolah Menengah Kejuruan kerja tingkat menengah sesuai dengan kompetensi dalam program keahlian yang dipilihnya; (2) menyiapkan peserta didik agar mampu memilih karier, ulet dan gigih dalam berkompetensi, beradaptasi di lingkungan kerja, dan mengembangkan sikap profesional dalam bidang keahlian yang diminatinya; (3) membekali peserta didik dengan ilmu pengetahuan, teknologi, dan seni, agar mampu mengembangkan diri dikemudian hari baik secara mandiri maupun melalui jenjang pendidikan yang lebih tinggi; dan (4) membekali peserta didik dengan kompetensikompetensi yang sesuai dengan program keahlian yang dipilih. A gar tujuan Sekolah Menengah 
Kejuruan Negeri tercapai diperlukan pendidik dan tenaga kependidikan yang berkualitas, sarana prasarana yang memadai, proses dan metode pembelajaran yang mendukung, serta pengelolaan yang baik (Kemendikbud, 2012).

SMKN 10 Bima adalah salah satu sekolah yang berada di kecamatan Palibelo Desa Belo, dengan posisi yang berada di pinggiran sawah merupakan sekolah yang berdiri sejak tahun 2010, meskipun sekolah tersebut tergolong sekolah yang baru di tengah masyarakat Desa Belo akan tetapi sekolah tersebut sudah mampu menarik minat masyarakat sekitar, hal itu dapat dilihat dari meningkatnya jumlah siswa dari tahun ketahun, sampai pada tahun 2018 jumlah siswa di SMKN 10 Bima sudah mencapai 272 orang bila dibandingkan jumlah siswa pada tahun 2013 yang hanya sekitar 150 orang saja, angka tersebut menunjukan peningkatan yang luar biasa bila dihitung secara statistik. SMKN 10 Bima sejauh ini telah menyiapkan guru/tenaga pengajar sebanyak 22 orang (PNS) dan 45 orang (Non PNS) dan jumlah itu terus meningkat seiring bertambahnya jumlah siswa. Pada saat ini sistem penilaian yang ada di SMKN 10 BIMA dirasa masih kurang karna sistemnya yang terbilang masih manual, karna penginputan nilai hasil belajar siswa hanya mengandalkan Microsoft world dan Microsoft exel sebagai instrumen penilaian sehingga efektifitas dan efisiensi kinerja para guru selalu terhambat yang berdampak pada lemahnya sistem pelayanan administrasi lembaga maupun siswa dan menimbulkan beberapa masalah yang dapat peneliti uraikan sebagai berikut.

Guru-guru yang ingin menginput nilai siswa harus menemui bagian pengolah data yakni operator yang kesibukannya cukup padat karna sifat penilaiannya yang masih bersifat manual, hal ini dirasakan sangat kurang efektif disebabkan bisa mengganggu kenyamanan guru diluar jam mengajar. Hal berikutnya yaitu tidak adanya privasi hak akses dalam menginput nilai karena setiap guru yang menggunakan aplikasi dapat menginputkan nilai untuk pelajaran apapun dan kelas berapapun, dan ini sangat beresiko terjadinya data terganti atau terhapus baik disengaja maupun tidak disengaja oleh pihak lain.

\section{Aplikasi}

Menurut (Syamsu Rizal, 2013), aplikasi adalah penggunaan dalam suatu perangkat komputer, instruksi (instruction) atau pernyataan (statement) yang disusun hingga sedemikian rupa, komputer dapat memproses masukan (input) menjadi keluaran (output).

Menurut Sri Widianti, aplikasi adalah sebuah software atau perangkat lunak yag bertugas sebagai font end pada sebuah sistem yang digunakan untuk mengolah berbagai macam data sehingga menjadi sebuah informasi yang bermanfaat untuk penggunanya dan juga sistem yang berkaitan.

\section{Raport}

Menurut (Tim Penyusun Kamus Pusat Pembinaan dan Pengembangan Bahasa, 1988), Raport adalah buku yang berisi keterangan mengenai nilai kepandaian dan prestasi belajar murid di sekolah, yang biasanya dipakai sebagai laporan guru kepada orang tua siswa atau wali murid. Raport mempunyai fungsi yang cukup penting, baik bagi siswa, orang tua, guru maupun wali kelas. dalam suatu unit tertentu.

\section{Kajian tentang aplikasi e-raport}

Dalam dokumen Panduan Penggunaan e-raport disebutkan aplikasi e-raport adalah perangkat lunak berbasis web maupun Bahasa pemprograman yang digunakan untuk menyusun laporan capaian kompetensi peserta didik oleh tingkat satuan pendidikan yang dikembangkan oleh Subdit Kurikulum Aplikasi e-rapor merupakan aplikasi untuk pengolahan nilai pengetahuan, nilai keterampilan, nilai sikap yang telah dilakukan oleh pendidik sehingga terbentuk nilai akhir beserta deskripsinya secara otomatisasi sesuai dengan perolehan siswa pada setiap kompetensi dasar yang 
dinilai, setelah wali kelas menginput nilai ekstrakurikuler, absensi siswa, perstasi, deskripsi sikap, serta catatan wali kelas maka e-rapor akan menyusunnya menjadi laporan capaian kompetensi siswa.

\section{Graphical User Interface (GUI) Menggunakan VB.Net 2010}

Menurut (Nanda Setiawan, 2013) GUI (Graphical User Interface) adalah antar muka pada sistem operasi atau komputer yang menggunakan menu grafis agar mempermudah para pengguna-nya untuk berinteraksi dengan komputer atau sistem operasi secara sederhana. Sedangkan Menurut (Vicky, 2012), GUI adalah suatu media virtual yang dapat membuat pengguna memberikan perintah tertentu pada komputer tanpa mengetik perintah tersebut, namun menggunakan gambar yang tersedia.

\section{Visual basic dan Visual Bacic Net 2010}

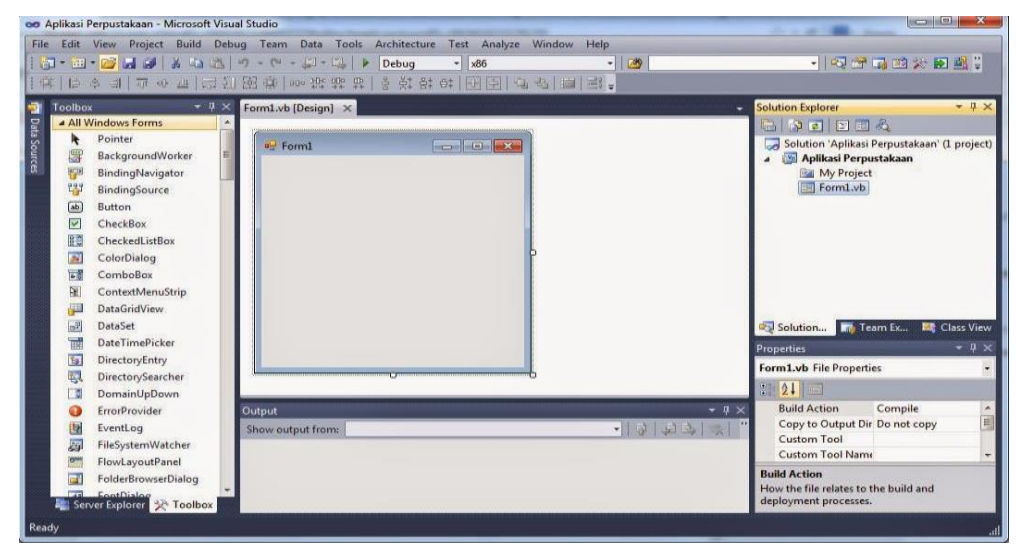

Gambar 1. Interface Visual Basic

Menurut (Sunyoto, 2007) "Visual Basic adalah Program untuk membuat aplikasi berbasis Microsoft Windows secara cepat dan mudah. Visual Basic menyediakan tool untuk membuat aplikasi yang sederhana sampai aplikasi kompleks atau rumit baik untuk perusahaan/instansi dengan sistem yang lebih besar".

Visual Basic Net 2010 atau yang biasa disebut Visual Studio 2010 pada dasarnya adalah sebuah bahasa pemrograman komputer. Dimana pengertian dari bahasa pemrograman itu adalah perintahperintah atau instruksi yang dimengerti oleh komputer untuk melakukan tugas-tugas tertentu.

\section{Use Case Diagram}

Use Case atau Use Case Diagram adalah pemodelan untuk menggambarkan behavior / kelakuan sistem yang akan dibuat. Use case diagram menggambarkan sebuah interaksi antara satu atau lebih aktor dengan sistem yang akan dibuat. Secara sederhana, diagram use case digunakan untuk memahami fungsi apa saja yang ada di dalam sebuah sistem dan siapa saja yang dapat menggunakan fungsi-fungsi tersebut. Tabel 2.1 Simbol-simbol Diagram Use Case

Tabel 1. Simbol-simbol Diagram Use Case

\begin{tabular}{|c|c|}
\hline Simbol & Deskripsi \\
\hline Use Case & $\begin{array}{l}\text { Use case adalah fungsionalitas yang disediakan sistem sebagai unit-unit } \\
\text { yang saling bertukar pesan antar unit atau actor. biasanya use case } \\
\text { diberikan penamaan dengan menggunakan kata kerja di awal frase } \\
\text { nama use case }\end{array}$ \\
\hline$\widehat{C}_{\text {nama aktor }}^{\text {Aktor / actor }}$ & $\begin{array}{l}\text { Aktor adalah orang, proses, atau sistem lain yang berinteraksi dengan } \\
\text { sistem informasi yang akan dibuat, jadi meskipun simbol dari aktor } \\
\text { ialah gambar orang, tapi aktor belum tentu merupakan orang. biasanya } \\
\text { penamaan aktor dinamakan menggunakan kata benda di awal frase } \\
\text { nama aktor }\end{array}$ \\
\hline
\end{tabular}




\begin{tabular}{|c|c|}
\hline Asosiasi / association & $\begin{array}{l}\text { Asosiasi adalah komunikasi antara aktor dan use case yang } \\
\text { berpartisipasi pada use case diagram atau use case yang memiliki } \\
\text { interaksi dengan aktor. Asosiasi merupakan simbol yang digunakan } \\
\text { untuk menghubungkan link antar element. }\end{array}$ \\
\hline $\begin{array}{l}\text { Ekstend / extend } \\
\text { <<extend }>>\end{array}$ & $\begin{array}{l}\text { Relasi use case tambahan ke sebuah use case dimana use case yang } \\
\text { ditambahkan dapat berdiri sendiri meski tanpa use case tambahan itu. } \\
\text { Arah panah mengarah pada use case yang ditambahkan }\end{array}$ \\
\hline $\begin{array}{l}\text { Include } \\
\text { <<include }>>\end{array}$ & $\begin{array}{l}\text { Relasi use case tambahan ke sebuah use case dimana use case yang } \\
\text { ditambahkan membutuhkan use case ini untuk menjalankan fungsinya } \\
\text { atau sebagai syarat dijalankan use case ini. Arah panah include } \\
\text { mengarah pada use case yang dipakai (dibutuhkan) atau mengarah } \\
\text { pada use case tambahan. }\end{array}$ \\
\hline $\begin{array}{l}\text { Generalisasi/ } \\
\text { generalization }\end{array}$ & $\begin{array}{l}\text { Hubungan generalisasi dan spesialisasi (umum - khusus) antara dua } \\
\text { buah use case dimana fungsi yang satu merupakan fungsi yang lebih } \\
\text { umum dari lainnya. Arah panah mengarah pada use case yang menjadi } \\
\text { generalisasinya (umum) }\end{array}$ \\
\hline
\end{tabular}

Tujuan Penelitian adalah 1) Menghasilkan raport yang terotomatisasi dari yang konvensional ke cara yang elektronik; 2) Menghasilkan e-raport yang dapat menghindari kesalahan penulisan secara manual serta membantu pengarsipan jika suatu saat dibutuhkan; 3) Mempermudah guru dalam menginput maupun memperbarui nilai rapor.

\section{METODE PENELITIAN}

\section{Model Pengembangan}

Pada pengembangan aplikasi ini peneliti menggunakan model pendekatan dengan metode waterfall, metode waterfall merupakan metode yang sering digunakan oleh penganalisa sistem pada umumnya. Inti dari metode waterfall adalah pengerjaan dari suatu sistem dilakukan secara berurutan atau secara linear. Jadi jika langkah ke-1 belum dikerjakan, maka langkah 2 tidak dapat dikerjakan. Jika langkah ke-2 belum dikerjakan maka langkah ke-3 juga tidak dapat dikerjakan, begitu seterusnya. Secara otomatis langkah ke-3 akan bisa dilakukan jika langkah ke-1 dan ke-2 sudah dilakukan.

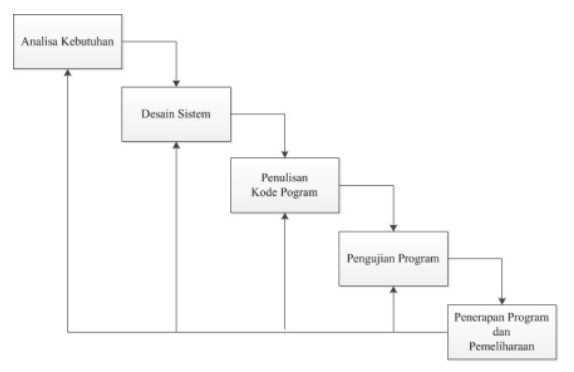

Gambar 2. model pengembangan waterfall

\section{Subjek Uji Coba}

Subjek uji coba dalam pengembangan aplikasi e-raport yaitu sekolah SMAN 10 Bima dengan tahapan sebagai berikut: 1) Tahap pertama uji coba skala kecil yaitu di kelas X Jurusan TKJ spesifiknya 5 orang siswa; 2) Tahap kedua uji coba skala besar dengan objek satu kelas sebanyak 24 siswa.

\section{Instrumen Pengumpulan Data}

Pengumpulan data dilakukan sebagai tahap awal analisa untuk mengidentifikasi masalah dana (kebutuhan). Adapun pengumpulan data dilakukan dengan: 1) Observasi, adalah cara menghimpun 
bahan-bahan keterangan (data) yang dilakukan dengan mengadakan pengamatan atau pencatatan secara sistematis terhadap fenomena-fenomena yang sedang dijadikan sasaran pengamatan.5 Observasi dilakukan pada saat pembelajaran berlangsung. Observasi dilakukan secara langsung untuk mengetahui keefektifan dari produk pengembangan; 2) Kuisioner (Angket), digunakan dalam memperoleh data dari ahli media dan materi; 3) Wawancara, peneliti melakukan wawancara kepada beberapa pihak sekolah maupun siswa secara langsung untuk mendapatkan informasi yang berkaitan sistem penilaian hasil belajar siswa; 4) Dokumentasi, mengumpulkan dokumen-dokumen data nilai siswa SMKN 10 Bima pada sistem yang berjalan saat ini.

\section{Teknik Analisis Data}

Teknik analisis data yang digunakan dalam penelitian dan pengembangan ini adalah pengumpulan data melalui instrumen kemudian dikerjakan sesuai dengan prosedur penelitian dan pengembangan. Adapun data yang dianalisis dalam perancangan aplikasi ini adalah data kuantitatif. Data kuantitatif diperoleh dari hasil angket yang dilakukan pada ahli media dan ahli materi, dalam sistem e-raport akan dikategorikan layak dugunakan apabila presentase dari pengguna sistem dapat memenuhi standar kriteria yang ditetapkan minimal 70\%. Dan rumus yang digunakan dalam teknik analisis data antara lain: 1) Analisis data angket validasi oleh ahli media; 2) Analisis data angket validasi oleh ahli materi (ahli data)

Data hasil penilaian terhadap kelayakan produk pengembangan produk e-raport milenium secara deskriptif. Penentuan tingkat kevalidan dan revisi produk seperti pada tabel 3.2.

Tabel 2. Tingkat Kevalidan dan Revisi Produk

\begin{tabular}{cll}
\hline Angka & Persentase (\%) & \multicolumn{1}{c}{ Kriteria Valid } \\
\hline 4 & $80 \leq$ M 100 & Valid (tidak perlu revisi) \\
3 & $60 \leq$ M 80 & Cukup valid (tidak perlu revisi) \\
2 & $40 \leq$ M 60 & Kurang valid (revisi) \\
1 & $0 \leq$ M 40 & Tidak valid (revisi) \\
\hline
\end{tabular}

Punaji Setyosari, Metode peneliti an pendidikan dan pengembangan, (Jakarta: Kencana, 2010), hal. 194.

Rumus nilai rata-rata yang digunakan pada kolom presentase adalah:

$$
\mathrm{P}=\frac{\text { Skor hasil pengumpulan data }}{\text { Skor ideal }} \times 100 \%
$$

Rumus yang digunakan untuk menentukan nilai akhir adalah:

$$
\mathrm{P}=\frac{\sum x}{\sum X i} x 100 \%
$$

Keterangan:

$\mathrm{P} \quad$ : Presentase yang dicari

$\sum X \quad$ : Jumlah jawaban responden

$\sum X_{i} \quad$ : Jumlah nilai ideal

Skor ideal= Skor tertinggi $\mathrm{x}$ Jumlah responden $\mathrm{x}$ Jumlah butir.

\section{HASIL DAN PEMBAHASAN}

\section{Analisis Data}

Penilaian validasi Ahli

Uji terhadap ahli media menggunakan skala likert dengan skor $=4$ Valid; untuk tingkat penilaian yang sangat tinggi, artinya tidak perlu revisi, = 3 Cukup Valid; untuk tingkat penilaian yang cukup tinggi, juga tidak perlu revisi, $=2$ Kurang valid; untuk tingkat penilaian yang cukup rendah, 
artinya diperlukan revisi atau perbaikan kembali, = 1 Tidak valid; untuk tingkat penilaian yang sangat rendah, artinya juga diperlukan revisi atau perbaikan kembali. Dari penilaian tersebut kemudian diinterprestasikan kelayakannya, dalam penggunaannya skala likert juga telah disediakan kotak saran untuk mengetahui kelebihan dan kekurangan masing-masing poin atau soal yang bersifat khusus, selain itu juga telah disediakan lembaran kosong yang tertera di bagian bawah tabel likert untuk masukan dan kritikan pada soal atau poin yang bersifat umum.

\section{Validasi Ahli Materi (Ahli Data)}

Validasi materi dilakukan oleh Ibu Nurrahmawati Fitriah S.Pd selaku wali kelas X jurusan TKJ di SMKN 10 Bima Hasil validasi ahli materi dapat dilihat pada tabel 4.1 sebagi berikut:

Tabel 3. Angket Validasi Ahli Materi

\begin{tabular}{|c|c|c|c|c|c|c|}
\hline No & Instrumen Pertanyaan & 1 & 2 & 3 & 4 & Saran \\
\hline 1 & Kejelasan judul aplikasi e-raport & & & & $\sqrt{ }$ & \\
\hline 2 & Kejelasan petunjuk penggunaan & & & $\sqrt{ }$ & & \\
\hline 3 & $\begin{array}{l}\text { Bahasa yang digunakan mudah } \\
\text { dipahami }\end{array}$ & & & & $\sqrt{ }$ & \\
\hline 4 & $\begin{array}{l}\text { Ketepatan dalam pemilihan font } \\
\text { (teks,angka, dan huruf) }\end{array}$ & & & & $\sqrt{ }$ & $\begin{array}{l}\text { Titelnya belum bisa } \\
\text { diberi huruf kecil }\end{array}$ \\
\hline 5 & $\begin{array}{l}\text { Kesesuaian dengan data yang diberikan } \\
\text { sekolah }\end{array}$ & & & & $\sqrt{ }$ & \\
\hline 6 & $\begin{array}{l}\text { Kesesuaian aplikasi e-raport dengan } \\
\text { kurukulum yang berlaku }\end{array}$ & & & & $\sqrt{ }$ & \\
\hline 7 & Kejelasan data & & & & $\sqrt{ }$ & $\begin{array}{l}\text { Tambahkan alamat } \\
\text { untuk data siswa }\end{array}$ \\
\hline 8 & Relevansi dengan data nilai siswa & & & & $\sqrt{ }$ & Cukup \\
\hline 9 & Kemudahan memahami data & & & $\sqrt{ }$ & & \\
\hline 10 & $\begin{array}{l}\text { Kalimat dan paragraph yang digunakan } \\
\text { jelas dan mudah dipahami }\end{array}$ & & & & $\sqrt{ }$ & Bagus \\
\hline & Jumlah & & & 6 & 32 & \\
\hline & Total & & & 38 & & \\
\hline
\end{tabular}

Analisis data dilakukan dengan cara menghitung persentase tingkat kevalidan, berdasarkan persentase hasil yang dinilai oleh ahli materi yaitu 95,55\% jika dicocokkan dengan tabel kriteria kelayakan, maka menunjukkan hasil validasi oleh ahli materi terhadap produk berupa pengembangan aplikasi e-raport termasuk dalam kriteria sangat layak dan tidak revisi.

Validasi Ahli Media

Validasi media dilakukan oleh Bapak Muliansani S.Kom., M.Kom. Hasil validasi ahli media dapat dilihat pada tabel 4 sebagi berikut:

Tabel 4. Angket Validasi Ahli Media

\begin{tabular}{cllllll}
\hline No & \multicolumn{1}{c}{ Instrumen Pertanyaan } & 1 & 2 & 3 & 4 & Saran \\
\hline 1 & $\begin{array}{l}\text { Tingkat kemudahan program dalam } \\
\text { menjalankan aplikasi e-raport }\end{array}$ & & & $\sqrt{ }$ & \\
2 & $\begin{array}{l}\text { Tampilan depan maupun isi aplikasi } \\
\text { e-raport/proposional layout cover } \\
\text { Ketepatan dalam pemilihan } \\
\text { background e-raport }\end{array}$ & $\sqrt{ }$ & $\sqrt{ }$ & & $\begin{array}{c}\text { Bancground baiknya } \\
\text { berubah setelah layout } \\
\text { Bancground baiknya } \\
\text { berubah setelah layout }\end{array}$ \\
\hline
\end{tabular}




\begin{tabular}{|c|c|c|c|c|}
\hline 4 & Kualitas tampilan aplikasi e-raport & & $\sqrt{ }$ & Simple \\
\hline 5 & $\begin{array}{l}\text { Ketepatan dalam penggunaan warna } \\
\text { pada aplikasi e-raport }\end{array}$ & $\sqrt{ }$ & & \\
\hline 6 & $\begin{array}{l}\text { Kesesuain jenis font, huruf, dan } \\
\text { angka dengan pemodelan pada } \\
\text { rancangan secara keseluruhan }\end{array}$ & $\sqrt{ }$ & & $\begin{array}{l}\text { Kalau bisa dengan } \\
\text { pewarnaan }\end{array}$ \\
\hline 7 & Kualitas gambar yang dihasilkan & & $\sqrt{ }$ & \\
\hline 8 & $\begin{array}{l}\text { Kemudahan dalam menggunakan } \\
\text { tombol navigasi }\end{array}$ & $\sqrt{ }$ & & $\begin{array}{l}\text { Lengkapi keterangan } \\
\text { fungsi menu }\end{array}$ \\
\hline \multirow[t]{3}{*}{9} & $\begin{array}{l}\text { Semua tombol dapat berfungsi } \\
\text { dengan baik }\end{array}$ & & $\sqrt{ }$ & \\
\hline & Jumlah & 15 & 16 & \\
\hline & Total & 31 & & \\
\hline
\end{tabular}

Analisis data dilakukan dengan cara menghitung persentase tingkat kevalidan, berdasarkan persentase hasil yang dinilai oleh ahli media yaitu $86 \%$, jika dicocokkan dengan tabel kriteria kelayakan, maka menunjukkan hasil validasi oleh ahli media terhadap produk berupa pengembangan aplikasi e-raport termasuk dalam kriteria sangat layak dan tidak revisi.

Uji Skala Kecil dan Skala Besar

Uji coba ini dimaksudkan untuk mengetahui kelayakan sistem dengan menggunakan data siwa yang telah di input, sehingga dapat diketahui apakah program layak atau tidak untuk digunakan.

\section{Uji Skala Kecil}

Uji skala kecil ini dilakukan terhadap 5 siswa kelas X Jurusan TKJ di SMKN 10 Bima. Hasil uji coba skala kecil dapat dilihat pada tabel 5 berikut:

Tabel 5. Hasil Uji Coba Kelompok Kecil

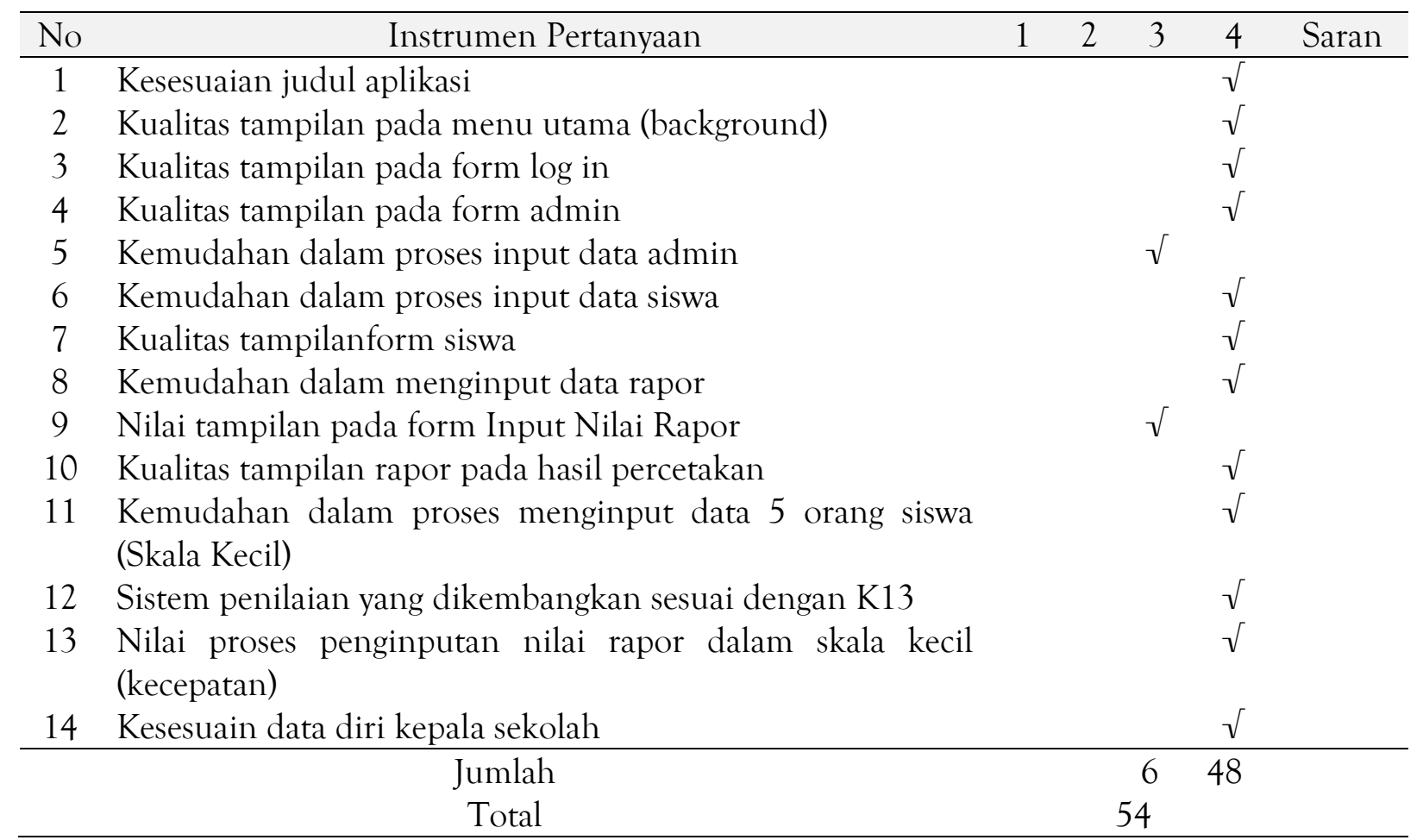

Analisis data dilakukan dengan cara menghitung persentase tingkat kevalidan, berdasarkan persentase hasil yang dinilai oleh admin dengan menggunakan skala kecil yaitu sebesar $96 \%$ jika 
dicocokkan dengan tabel kriteria kelayakan, maka menunjukkan hasil validasi skala kecil terhadap produk berupa pengembangan aplikasi e-raport termasuk dalam kriteria sangat layak dan tidak revisi.

Uji Skala Besar

Uji skala besar ini dilakukan terhadap 24 orang siswa kelas XI jurusan TKJ di SMKN 10 Bima. Hasil Uji coba skala besar dapat dilihat pada tabel 6 berikut

Tabel 6. Hasil Uji Coba Kelompok Besar

\begin{tabular}{|c|c|c|c|c|c|c|}
\hline No & Instrumen Pertanyaan & 1 & 2 & 3 & 4 & Saran \\
\hline 1 & Kesesuaian judul aplikasi & & & & $\sqrt{ }$ & \\
\hline 2 & Kualitas tampilan pada menu utama (background) & & & & $\sqrt{ }$ & \\
\hline 3 & Kualitas tampilan pada form log in & & & & $\sqrt{ }$ & \\
\hline 4 & Kualitas tampilan pada form admin & & & & $\sqrt{ }$ & \\
\hline 5 & Kemudahan dalam proses input data admin & & & & $\sqrt{ }$ & \\
\hline 6 & Kemudahan dalam proses input data siswa & & & $\sqrt{ }$ & & \\
\hline 7 & Kualitas tampilan form siswa & & & & $\sqrt{ }$ & \\
\hline 8 & Kemudahan dalam menginput data rapor & & & $\sqrt{ }$ & & \\
\hline 9 & Nilai tampilan pada form Input Nilai Rapor & & & & $\sqrt{ }$ & \\
\hline 10 & Kualitas tampilan rapor pada hasil percetakan & & & & $\sqrt{ }$ & \\
\hline 11 & $\begin{array}{l}\text { Kemudahan dalam proses menginput data } 24 \text { orang } \\
\text { siswa (Skala Besar) }\end{array}$ & & & $\sqrt{ }$ & & \\
\hline 12 & Sistem penilaian yang dikembangkan sesuai dengan K13 & & & & $\sqrt{ }$ & \\
\hline 13 & $\begin{array}{l}\text { Nilai proses penginputan nilai rapor dalam skala besar } \\
\text { (kecepatan) }\end{array}$ & & & & $\sqrt{ }$ & \\
\hline 14 & Kesesuain data diri kepala sekolah & & & & $\sqrt{ }$ & \\
\hline & Jumlah & & & 9 & 44 & \\
\hline & Total & & & & & \\
\hline
\end{tabular}

Analisis data dilakukan dengan cara menghitung persentase tingkat kevalidan, berdasarkan persentase hasil yang dinilai oleh admin dengan menggunakan skala besar yaitu sebesar $95 \%$ jika dicocokkan dengan tabel kriteria kelayakan, maka menunjukkan hasil validasi skala besar terhadap produk berupa pengembangan aplikasi e-raport termasuk dalam kriteria sangat layak dan tidak revisi.

\section{KESIMPULAN}

Berdasarkan penelitian yang peneliti lakukan melalui analisa data dari angket yang disebarkan, wawancara dan observasi makaa dapat ditarik kesimpulan sebagai berikut: 1) Penelitian yang dilakukan merupakan penelitian pengembangan dengan dilakukan lima tahap pengembangan, dalam penelitian ini meliputi tahap Analisis kebutuhan, Desain sistem, Penulisan kode, Pengujian program, dan penerapan maupun pemeliharaan, dalam pegembangannya aplikasi yang dikembangkan cukup baik karna sudah berbasis desktop tampa harus harus mengerjakan rapor dengan cara manual; 2) Penelitian yang dilakukan menghasilkan produk aplikasi sistem e-raport millennium dengan menggunakan Visual Basic Net.2010 dengan tampilan, model, maupun tampilan yang cukup menarik dengan berbagai kemudahan dalam pengaplikasiannya; 3) Sistem yang dirancang mampu menghasilkan raport yang sudah terotomatisasi hingan menjadi rapor yang efektif, efisien, dan praktis dalam penggunaannya; 4) Kualitas produk termasuk kriteria "Layak" dengan rata-rata presentasi 80\% -95\%. Dan sudah memenuhi standar ktiteria yang ditetapkan yakni sebesar 70\%, itu dapat dilihat dari hasil angket yang dilakukan kepada ahli materi dengan hasil angket berupa "layak", ahli edia dengan hasil angket berupa "layak", uji dengan kelompok kecil dengan hasil angket berupa "layak", dan uji dengan kelompok besar dengan hasil angket berupa "layak" 


\section{Daftar Pustaka}

Agusdar. 2013. "Metode Pengembangan Sistem Waterfall”.

Ardi, 2016. "Pengenalan Visual Basic”.

Anonim 1. 2016. "Pengertian Aplikasi Menurut Para Ahli dengan Sumbernya.".

Anonim 2. 2013. "Pengertian dan Sejarah Microsoft Visual Studio 2010”. Tersedia pada, http://www.tugassekolah.info/pengertian-dan-sejarah-microsoft-visual-studio-2010/ di akses Senin, 10 Maret 2018, pukul 23.25 WITA.

Anonim 3. 2016. "Pengertian Analisis Data Menurut Ahli.". Tersedia pada, http://googleweblight.com/i?u=http://metlitblog.wordpress.com/2016/11/25/pengertiananalisis-data-menurut-ahli/\&hl=id-ID, di akses Minggu, 18 Maret 2018, pukul 18.30 WITA.

Budi.Eko. 2016. "Aplikasi e-Rapor SMA Kurikulum 2013”. Tersedia pada http://fxekobudi.net/tikdi-sekolah/aplikasi-e-rapor-sma-kurikulum-2013/. Di akses Senin, 6 Maret 2018, pukul 22.32 Wita.

Dwi Feni.2016."Pengertian R\&D Penelitian dan Pengembangan”. Tersedia pada http://www.karyatulisku.com/2016/04/pengertian-r-penelitian-dan-pengembangan.html. Diakses Senin, 15 Februari 2017, pukul 13.14 WITA.

Gunawan. Erik, 2014. “Use Case Diagram”. Tersedia pada https://www.erikgunawan.com/use-casediagram/. Di akses Senin, 6 Maret 2018, pukul 23.36 WITA.

Hamid,Abdul (2016). Perancangan Aplikasi Penilaian Rapor siswa di SMKN 2 Kota Bima dengan menggunakan PHP dan MYSQL, Bima: STKIP TSB press.

IJNS - Indonesian Journal on Networking and Security. 2013. ISSN: 2302-5700 "Pengolahan Raport Siswa Pada Smp Negeri 3 Kebonagung" .Tersedia pada http://portalgaruda.ilkom.unsri.ac.id/index.php?ref=browse\& mod=viewarticle\&article=26913 1. Diakses Rabu, 13 Maret 2018, pukul 13.37 WITA

Kemdikbud. 2012. Analisis Pendidikan Kewirausahaan Di Sekolah Menengah Kejuruan Analysis Of Enterpreneurship Education At Senior Vocational School: Jurnal Pendidikan dan Kebudayaan, Vol. 18, Nomor 2, Juni 2012

Marizka.Arbani. 2011.Pengembangan Sistem Informasi Sekolah Berbasis Web”. Tersedia padahttp://repository.uinjkt.ac.id/dspace/bitstream/123456789/2702/1/MARIZKA\%20ARB ANI-FST.pdf di akses Rabu, 14 Februari 2018, pukul 10.30 WITA

Nanda Setiawan. 2013. "Pengertian dan definisi dari GUI". Tersedia pada http://nandask.blogspot.co.id/2013/04/pengertian-dan-definisi-dari-gui.html di akses Selasa, 13 Februari 2018, pukul 10.00 WITA.

Uda Iwak. 2015. "Menelisik Fungsi Buku Rap (Feni, 2016)or Siswa”. Tersedia pada

https://www.matrapendidikan.com/2015/08/menelisik-fungsi-buku-rapor-siswa.html, di akses Senin, 15 Januari 2018, pukul 14.35 WITA.

Vicky, 2012. "Pengertian dan sejarah singkat GUI" .Tersedia pada http://belajar-komputermu.com/pengertian-dan-sejarah-singkat-gui/. Diakses Senin, 15 Januari 2018, pukul 13.34 WITA. 